A C T A C H E M I C A S C A N D I N A V I C A 17 (1963) S $174-$ S 179

\title{
Fermentation as a Means of Preserving Organic Materials*
}

\author{
RAGNAR NILSSON and CONRAD RYDIN
}

Mikrobiologiska Institutionen, Lantbrukshögskolan, Uppsala, Sweden

\begin{abstract}
In ensiling both vegetable and animal material, first-class silage is obtained if sufficient quantities of a meal mixture consisting of enzymerich malt and cereal are added to the fresh, finely divided fodder. This meal mixture supplies the organic material with lactic-acid bacteria and furthermore with the amino acids and vitamins which these bacteria require for their growth, and above all, with carbohydrates (starch), which are hydrolysed by the enzymes in the malt to sugar fermentable by the lactic-acid bacteria.

In ensiling forage 'crops with malt-cereal meal, it was found that the effluent can safely be kept in the silo by absorption in chopped straw mixed with the green fodder, thus avoiding large losses of nutrients from the fodder and rather heavy contamination of the surrounding water recipients.

Dried silage of fish, beef and blood, ensiled with malt-cereal meal, proved to be unobjectionable from a sanitary point of view.

Hens were fed for 18 months with silages made from rumen contents, fish and pigs' blood. Their state of health and egg production were good; the eggs and carcasses were of good quality and did not give any unpleasant taste or smell.

This new means of preserving organic matter is so simple that it can be practised at sea, using absolutely fresh fish which is directly ground together with the malt-cereal meal. There also appears to be a possibility of producing, after the necessary modifications, a cheap protein of biologically full value for human consumption.
\end{abstract}

Tn silage-making by purely biological processes the basis of positive conservation 1 of the organic material is a lactic-acid fermentation which sets in so rapidly and is so intense that it extinguishes all other, undesirable, microbial or enzymatic activities. In order to make possible such a lactic-acid fermentation, relatively large quantities of carbohydrates fermentable by lactic-acid bacteria are required. In many types of feed- and foodstuffs the lack of such carbohydrates often limits the production of an efficient lactic-acid fermentation. Examples of such materials are lucerne, clover, brewer's grains, potatoes and, above all, animal products such as meat, fish, blood and slaughterhouse waste.

* United Nations Conference on the Application of Science and Technology for the Benefit of the Less Developed Areas, Genève 4-20 Feb. 1963. Agenda Item: D.4.2.

Acta Chem. Scand. 17 (1963) Suppl. 1 
The types of lactic-acid bacteria, which appear to be responsible for most of the lactic-acid production, ferment different types of sugar, including certain pentoses (xylose, arabinose) as well as hexoses (glucose, fructose, galactose) and disaccharides (sucrose, maltose), producing chiefly lactic acid but also smaller quantities of acetic acid. Polysaccharides such as dextrin and starch are consider ably more difficult to ferment than these sugars.

In ensiling experiments with green fodder, in which different enzyme preparations with high amylase and cellulase activities, either alone or together with cereal meal, were added to material of low sugar content, it was possible to hydrolyse to a high degree polysaccharides not fermentable by lactic acid bacteria into fermentable sugar, so that a sufficient lactic-acid fermentation was produced to preserve the fodder properly. A meal of enzyme-rich malt produced by special methods from six-rowed barley proved to be particularly suitable for this purpose. Of particular interest is the ability of the enzymes in malt to attack and hydrolyse the raw native starch. In this hydrolysis $\alpha$-amylase is an active enzyme. This enzyme does not exist in ungerminated grain but is formed during germination.

Besides the effect of the carbohydrases in the malt, the addition of the mixture of enzyme-rich malt-cereal meal (usually mixed in the ratio of $1: 5$ ) promotes the lactic-acid fermentation in the silage, owing to the fact that the meal mixture has a high content of various Lactobacillus species and therefore the addition of meal is accompanied by substantial inoculation with desirable microorganisms. The ensiling malt has a high content of certain free amino acids (valine, leucine, isoleucine, threonine, methionine, glutamic acid, tryptophane, phenylalanine) and certain $B$ vitamins (riboflavine, $B_{6}$, pantothenic acid, biotin), which the heterotrophic lactic-acid bacteria require for their growth. After the addition of this malt-cereal mixture the lactic-acid bacteria in the silage seem to have optimal conditions as regards the substrate, which leads to rapid and substantial lactic-acid fermentation and thereby a good result in the ensiling. We would point out that, even without the addition of malt, meal of various kinds of cereal contains large amounts of lactic-acid bacteria and in addition smaller amounts of carbohydrates fermentable by lactic-acid bacteria and also growth factors for these bacteria. The addition of large quantities of cereal meal, without the simultaneous addition of malt, may therefore yield good results. However, the large quantities of cereal which are required in this connection and the uncertainty involved in the use of this supplement limit to a great extent the use of cereal meal alone as a supplement in ensiling.

Good-quality silage is characterized by low figures for ammonia nitrogen as a percentage of total nitrogen $\left(\mathrm{NH}_{3}-\mathrm{N}\right.$ of total $\left.\mathrm{N}\right)$; this figure should be less than about 12 and furthermore butyric acid must only occur in insignificant quantities.

The losses during fermentation are greatly limited if vigorous lactic-acid fermentation is started rapidly and also if the effluent is not drawn off but allowed to remain in the silo, thereby being utilized as fodder. Silage appetizing to cattle has a high content of lactic acid and often some sugar also.

The results of some ensiling experiments with the addition of malt-cereal meal to various kinds of fodder will now be presented. The ensilings were carried out on a laboratory scale in silos of stainless steel containing 12-16 kg green fodder 
Table 1. The effect of barley meal and malt-barley meal on the fermentation process in ensiling a crop of lucerne-grass. Ensiling time, 8 weeks. Temperature, $28^{\circ} \mathrm{C}$.

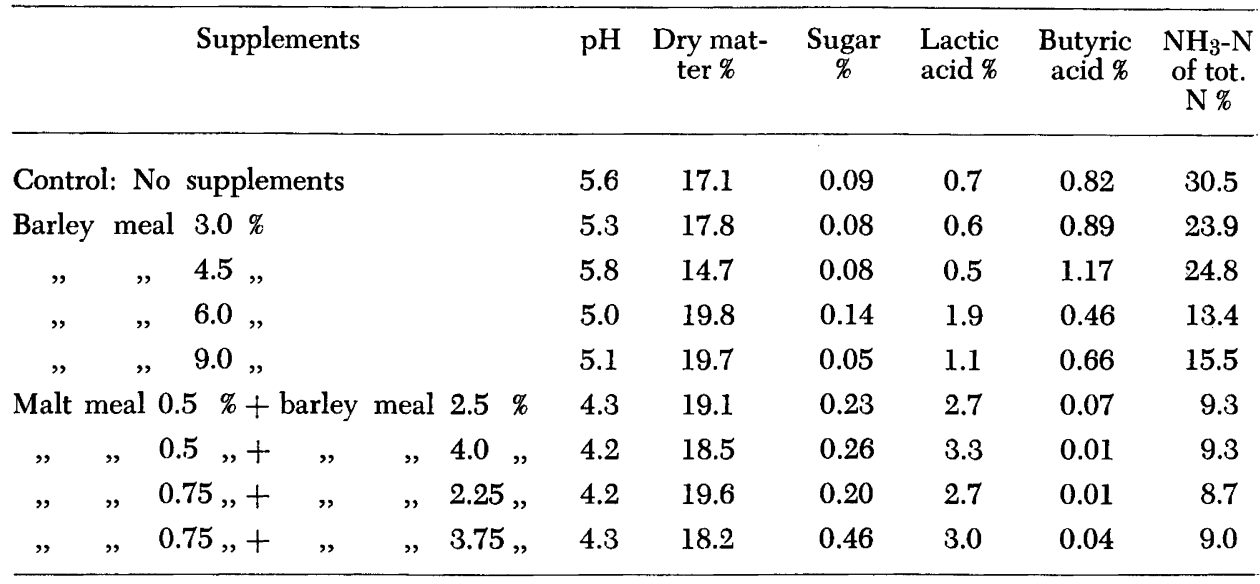

and in smaller silos of glass containing $2-3 \mathrm{~kg}$ fish, meat, blood, rumen contents and rumen wall. Effluent was not drawn off.

Table 1 shows analyses of lucerne-grass silage, partly without supplement and partly with the addition of various amounts of barley meal or mixtures of maltand barley meal. It is clear from these analyses that the silages without supplement and with $3 \%$ or $4.5 \%$ of barley meal were a complete failure; $6 \%$ or $9 \%$ of barley meal improved the quality, though not to such an extent that the silage could be regarded as satisfactory. The supply of sugar fermentable by the lacticacid bacteria was not sufficient to achieve sufficiently intense lactic-acid fermentation. The addition of $3 \%$ or $4.5 \%$ of mixtures of malt- and barley meal resulted in first-class silage. The enzymes in the malt attacked and sufficiently hydrolysed the starch in the meal mixtures, so that an adequate quantity of sugar was available for the lactic-acid bacteria. In the silages with a malt supplement lactic-acid fermentation greatly predominated, thus largely precluding the processes of decomposition and butyric-acid fermentation. Silages with low contents of butyric acid often have low contents of spores of butyric-acid bacteria, a fact which may be of importance when silage is fed to cows whose milk is used in the production of certain kinds of cheese.

Animal material such as fish (cod and herring), meat, rumen contents, rumen wall, blood and the like have been successfully ensiled by admixture of maltcereal meal to the finely ground, fresh material. Within the temperature range of $20-28^{\circ} \mathrm{C}$ the material can safely be kept for 4 weeks. After that lower storage temperatures should be aimed at. As far as is known up to the present, however, there is no objection to using the material even before complete fermentation. The lactic-acid fermentation is essential when it is a question of conserving the material, but does not seem to be necessary to make it suitable as a feed-stuff, though it seems possible to foresee that this fermentation may be of great im- 
Table 2. The effect of oats meal and malt-oats meal on the fermentation process in ensiling small Baltic herring. Ensiling time, 4 weeks. Temperature, $28^{\circ} \mathrm{C}$.

\begin{tabular}{|c|c|c|c|c|c|c|c|}
\hline \multicolumn{3}{|c|}{ Supplements } & $\mathrm{pH}$ & $\begin{array}{l}\text { Dry mat- } \\
\text { ter } \%\end{array}$ & $\begin{array}{l}\text { Lactic } \\
\text { acid \% }\end{array}$ & $\begin{array}{l}\text { Butyric } \\
\text { acid \% }\end{array}$ & $\begin{array}{l}\mathrm{NH}_{3}-\mathrm{N} \text { of } \\
\text { tot. N\% }\end{array}$ \\
\hline \multicolumn{3}{|c|}{ Control: No supplements } & 7.3 & 14.9 & 0.6 & 2.91 & 55.4 \\
\hline \multicolumn{3}{|c|}{ Oats meal $20 \%$} & 6.8 & 32.3 & 0.5 & 3.18 & 38.8 \\
\hline \multicolumn{3}{|l|}{ " } & 5.5 & 35.8 & 3.3 & 1.05 & 25.4 \\
\hline & & & 4.9 & 46.2 & 4.6 & 0.04 & 15.9 \\
\hline \multicolumn{3}{|c|}{ Malt meal $2 \%+$ oats meal $18 \%$} & 4.5 & 34.6 & 5.7 & 0.01 & 14.2 \\
\hline$"$ & $2 "+"$ & 23, & 4.4 & 34.2 & 5.7 & 0.01 & 13.3 \\
\hline$"$ & $2 "+"$ & 28, & 4.4 & 45.3 & 4.9 & 0.01 & 11.3 \\
\hline Malt meal & $4 \%+$ oats meal & $16 \%$ & 4.6 & 34.4 & 5.4 & 0.01 & 12.6 \\
\hline$"$ & $4,+\#$ & $21 "$ & 4.5 & 37.7 & 5.4 & 0.01 & 12.3 \\
\hline " & $4,+$, & $26 "$ & 4.5 & 45.4 & 5.0 & 0.01 & 10.8 \\
\hline
\end{tabular}

portance as regards material infected with pathogenic germs. Silage made with the kinds of fodder mentioned is easy to dry. The result of ensiling experiments with animal material will now be presented.

Table 2 shows analyses of silage of small Baltic herring, which, after having been ground in an ordinary meat-mincer were ensiled partly without and partly with an addition of either oats meal or malt- and oats meal in various mixing ratios and quantities. When sufficient amounts of the mixture of malt- and oats meal were added to the material, the quality of the silage was first-class. Silage with this supplement was incomparably better than silage with a similar supplement of oats meal alone.

Table 3. The effect of malt-barley meal on the fermentation process in ensiling small Baltic herring. Ensiling time, 4 weeks. Temperature 20,28 or $37^{\circ} \mathrm{C}$.

\begin{tabular}{|c|c|c|c|c|c|c|c|}
\hline$\underset{{ }^{\circ}}{\text { Temp. }}$ & Supplements & & $\mathrm{pH}$ & $\underset{\%}{\operatorname{Sugar}}$ & $\begin{array}{l}\text { Lactic } \\
\text { acid \% }\end{array}$ & $\begin{array}{c}\text { Butyric } \\
\text { acid \% }\end{array}$ & $\begin{array}{c}\mathrm{NH}_{3}-\mathrm{N} \text { of } \\
\text { tot. } \mathrm{N} \%\end{array}$ \\
\hline 28 & Control: No supplement & & 7.1 & - & 0.6 & 1.98 & 43.9 \\
\hline \multirow[t]{3}{*}{20} & Malt meal $4 \%+$ barley & meal $20 \%$ & 4.3 & 3.5 & 5.2 & 0.01 & 8.0 \\
\hline & " $6,+$, & " $30 "$ & 4.4 & 5.4 & 4.8 & 0.01 & 7.4 \\
\hline & , $8,+$ & $\Rightarrow 40$, & 4.4 & 6.5 & 4.7 & 0.01 & 7.6 \\
\hline \multirow[t]{3}{*}{28} & Malt meal $4 \%+$ barley & meal $20 \%$ & 4.3 & 3.4 & 5.0 & 0.01 & 8.9 \\
\hline & $" 6,+\Rightarrow$ & " 30, & 4.4 & 5.1 & 4.8 & 0.01 & 7.7 \\
\hline & $" 8,+$, & " $40 "$ & 4.3 & 6.9 & 4.5 & 0.01 & 7.7 \\
\hline \multirow[t]{3}{*}{37} & Malt meal $4 \%+$ barley & meal $20 \%$ & 4.2 & 1.0 & 5.9 & 0.23 & 12.8 \\
\hline & $\Rightarrow \quad, \quad, \#$, & " 30 , & 4.1 & 2.3 & 5.5 & 0.12 & 10.3 \\
\hline & $" 8,+$, & $" 40$, & 4.1 & 4.4 & 5.0 & 0.04 & 9.9 \\
\hline
\end{tabular}

Acta Chem. Scand. 17 (1963) Suppl. 1 
Table 4. The effect of malt meal and cereal (oats-barley) meal (1:5) on the fermentation process in ensiling cod-fish, beef and pigs' blood. Ensiling time, $7-10$ days. Temperature, $28^{\circ} \mathrm{C}$.

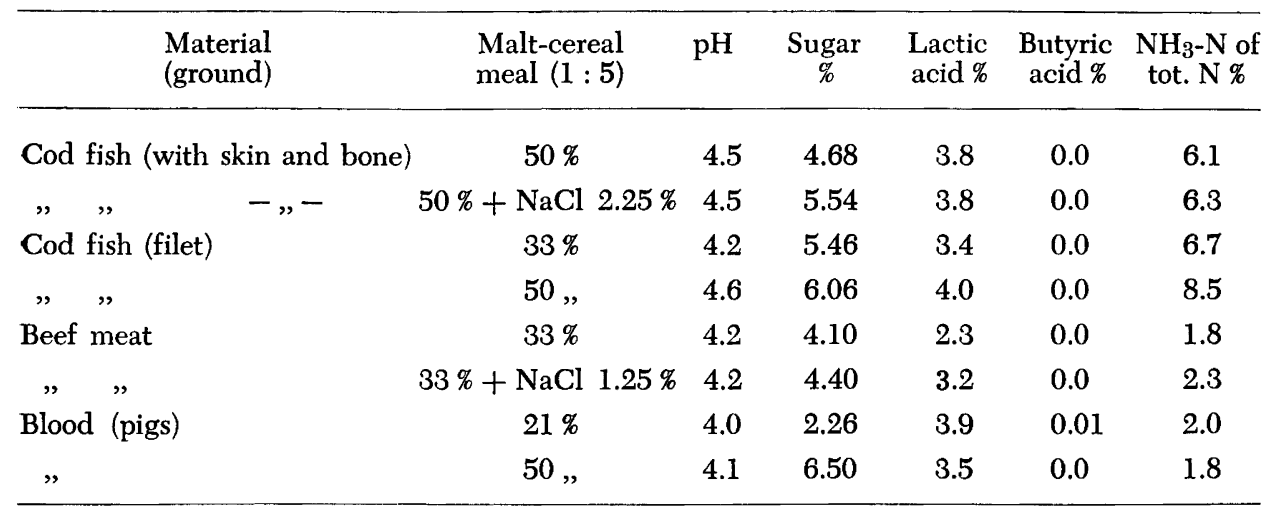

Table 3 shows analyses of silage of small Baltic herring with malt-barley meal $(1: 5)$ in various quantities and ensiled at different temperatures. Fermentation temperatures of $20-28^{\circ} \mathrm{C}$ throughout yielded first-class silage. At $37^{\circ} \mathrm{C}$ the quality was poorer. It is nevertheless obvious that there is a possibility of utilizing sensitive organic material by this method even under tropical conditions.

The usefulness of the method, as concerns animal material, may be illustrated by Table 4 . This table shows silage analyses of animal material which may possibly be used as food for human consumption. As is evident, very large quantities of the malt-cereal mixture were used. This was in order to guarantee a very rapid lactic-acid fermentation and thereby an effective inhibition of the processes of decomposition and consequently toxin formation. The very high contents of sugar in these silages indicate that probably unnecessarily large quantities of the meal mixture were used.

Dried silages made from cod-fish, meat and blood, using our method, have been investigated bacteriologically by the Swedish National Institute of Public Health and found to be unobjectionable as regards human consumption. Further ensiling experiments with animal products, including infection experiments with pathogenic bacteria, must certainly be carried out before such silage can be recommended for human consumption.

Table 5 shows the results of ensiling the contents of the rumens of slaughtered cows. As the table shows, malt-cereal meal ( $1: 5)$, together with straw meal, was used as a supplement.

The rumen contents of slaugtered cows vary in weight between 60 and $90 \mathrm{~kg}$ per animal. The dry-matter content is low but the content of vitamins (thiamine, riboflavin, nicotinic acid, $B_{12}$ ) and valuable protein from micro-organisms is relatively high.

It is clear from the table that the non-fermented rumen contents held a few tenths per cent of lactic acid and butyric acid. By the addition of malt-cereal meal a satisfactory silage for animal feeding is obtained.

Silage made from the contents of the rumens of slaughtered cows which had 
Table 5. The effect of malt meal and cereal (oats-barley) meal (1:5) and straw meal on the fermentation process in ensiling rumen contents from slaughtered cows. Ensiling time, 10 days. Temperature, $28^{\circ} \mathrm{C}$.

\begin{tabular}{|c|c|c|c|c|c|c|}
\hline Supplements & $\mathrm{pH}$ & $\begin{array}{l}\text { Dry mat- } \\
\text { ter } \%\end{array}$ & $\underset{\%}{\text { Sugar }}$ & $\begin{array}{l}\text { Lactic } \\
\text { acid \% }\end{array}$ & $\begin{array}{l}\text { Butyric } \\
\text { acid \% }\end{array}$ & $\begin{array}{l}\mathrm{NH}_{3}-\mathrm{N} \text { of } \\
\text { tot. } \mathrm{N} \%\end{array}$ \\
\hline $\begin{array}{l}\text { Control: No supplements, } \\
\text { not fermented }\end{array}$ & 6.9 & 11.3 & 0.08 & 0.2 & 0.15 & 5.4 \\
\hline Control: $\begin{array}{l}\text { No supplements, } \\
\text { fermented }\end{array}$ & 5.6 & 9.6 & trace & 0.2 & 0.32 & 25.3 \\
\hline $\begin{array}{l}\text { Malt-cereal-meal }(1: 5) 6 \%+\text { straw } \\
\quad \text { meal } 6 \%\end{array}$ & 4.3 & 16.5 & 0.11 & 1.8 & 0.36 & 13.6 \\
\hline $\begin{array}{l}\text { Malt-cereal-meal } 9 \%+\text { straw meal } \\
9 \%\end{array}$ & 4.2 & 19.1 & 0.19 & 2.1 & 0.36 & 12.7 \\
\hline $\begin{array}{l}\text { Malt-cereal-meal } 12 \%+\text { straw meal } \\
\quad 12 \%\end{array}$ & 4.0 & 22.4 & 0.88 & 2.3 & 0.34 & 11.6 \\
\hline
\end{tabular}

been at pasture was fed fresh to hens. Dried and ground silage made from the contents of the rumens of slaughtered cows which had been stable-fed was fed to pigs. Both these kinds of animals consumed the silages with avidity.

Small-scale feeding experiments have been going on for 18 months at the Department of Microbiology with hens $(2 \times 24)$, which are fed with fresh or dried silage made from clover-grass, rumen contents, rumen wall, fish and blood. The laying percentage is $60-70 \%$. It has not been possible to demonstrate any fishy taste in the eggs or in the carcases. The quality of the egg shell is good.

Our ensiling method, using vegetable crops, has been applied full-scale under practical conditions on Swedish farms in altogether about 100 ensilings during the past 5 years with good results.

Received April 2, 1963. 